\section{The influence of formal institutions on the internationalization of companies in an emerging country}

\author{
Jefferson Marlon Monticelli \\ University of Vale do Rio dos Sinos, School of Business \& Management, \\ Administration Postgraduate Program, São Leopoldo, RS, Brazil
}

\section{Cyntia Vilasboas Calixto}

Getulio Vargas Foundation, School of Business Administration

of São Paulo, São Paulo, SP, Brazil

Sílvio Luís de Vasconcellos

University of Vale do Itajai, Biguaçu Unit, Business

Postgraduate Program, Biguaçu, SC, Brazil

\section{Ivan Lapuente Garrido}

University of Vale do Rio dos Sinos, School of Business \& Management, Administration Postgraduate Program, São Leopoldo, RS, Brazil

\begin{abstract}
Purpose - The goal of this study is to use the institution-based view as the background for an investigation of how formal institutions influence the internationalization processes of firms from an emerging economy.
\end{abstract}

Design/methodology/approach - Our case study is based on semistructured interviews with twenty-one representatives of formal institutions and firms in the Brazilian wine industry.

Findings - It was noted that formal institutions have positive influences on the internationalization of Brazilian wineries by providing learning, relationship networks, intelligence about foreign markets, costs reduction, internationalization of business processes, and by promoting the home country's image as a wine producer in foreign markets, and as a recognized supplier to the domestic market. They also have negative influences, as excessive bureaucracy, strikes, erection of legal barriers to trade with other countries, insufficient technical knowledge, high taxes, and favoritism benefiting the largest wine producers in the industry.

Originality/value - The paper closes with suggestions for future research on how phenomena such as the relationship strategies established by the wineries impact upon internationalization and how decisions of a political nature made by formal institutions influence the wine industry, providing a new outlook on the internationalization of these firms.

Keywords - Institutions in emerging economies; formal institutions; institutional environment; neo-institutional theory; competitive strategies of multinational enterprises.
Received on

03/01/2016

Approved on

02/07/2017

\section{Responsible editor:}

Prof. Dr. Francisco Diez Martin

Evaluation process:

Double Blind Review

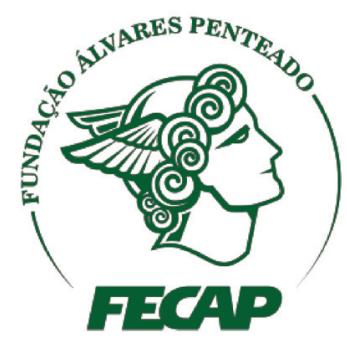

Review of Business Management

DOI: $10.7819 /$ rbgn.v0i0.3040 


\section{Introduction}

Firms in emerging economies are committed to internationalize processes as a mean of protecting themselves from the turmoil existing in their domestic markets. According to Fleury and Fleury (2011), Brazilian firms have been late to internationalize because of the country's physical size (which provides them with a large domestic market), because of a lack of government incentives, and because of the protectionist measures that isolated the domestic market up to the 1990s. The local government is encouraging Brazilian firms to operate abroad, thereby changing the dynamics of business. In turn, the strength of the domestic market discourages some firms from diversifying their operations, since operating in unfamiliar environments imposes greater costs and risks (Rocha, Silva, \& Carneiro, 2007).

Institutional theory has been used to complement the industry-based view and resource-based view - and has come to be known as an institution-based view (Gao, Murray, Kotabe, \& Lu, 2010; Peng, 2002; Peng \& Khoury, 2008). This perspective has focused on understanding how institutional mechanisms function and what influence they have on the strategy and performance of firms. However, few studies conducted within the internationalization agenda have focused on aspects of the institutional environment in the country of origin. This is particularly true about research investigating emerging economies and the firms based in them. Research interest in institutional environments has tended to concentrate on how host country's factors influence direct foreign investment and entry mode decisions.

In emerging economies, the relationships between firms and institutions normally involve considerable information asymmetries and high transaction costs, and product diversification is encouraged in order to minimize risks. In developed countries, the opposite characteristics prevail, encouraging firms to narrow their product lines, which in turn leads them to base their sources of competitiveness on efficient production or economies of scope (Meyer \& Peng, 2005).

From a theoretical perspective, this article seeks to understand the influence that formal institutions exert on the internationalization processes of firms from emerging economies. This study is an attempt to answer the following research question: How do formal institutions influence internationalization of firms from emerging economies? In order to answer it, we draw support from neo- institutionalist theory, the institution-based view, and theories of internationalization. The empirical field of study is the Brazilian wine industry, specifically wineries located in the country's Southern region, which is the largest wine producer and exporter out of Brazil's five administrative regions. This industry is suitable for this study due to its location, because it has many different firms of varying sizes and degrees of experience, and because it enjoys formal institutional support for seeking out foreign markets.

\section{Literature review}

Neo-institutionalism argues that political and social environments are organized through institutions and attempts to explain the impact of the structures they establish on the behavior and economic performance of organizations (Hoskisson, Eden, Lau, \& Wright, 2000; North, 1990). In an economic context, the influence of institutions has the effect of encouraging firms to redefine their strategies. Institutions have evolved as a response to imperfections in the functioning of economic structures in markets (North, 1990).

\section{I Institutionalization and institutions}

Organizational institutionalism focuses on institutions and processes, primarily at the organizational level. It inserts organizations into a different context to enable the analysis of their interactions with internal and external environments, striving to ensure their continuity in the midst of contextual pressures and, 
therefore, situates the analysis within the resulting organizational model (Greenwood, Oliver, Suddaby, \& Sahlin, 2008).

Scott (2001) puts greater emphasis on the limitations or demands that the institutional environment imposes on organizations attempting to ensure their own survival, whether imposed through regulatory, normative, or cognitive-cultural elements. He also describes the institutional environment as the set of rules and requirements that organizations must abide by to obtain the expected support and legitimacy from the environment in which they operate.

The more stringent the rule is, the greater its impact on society; the weaker it is, the greater the flexibility and, therefore, the less influence it has to change social structures (Hollingsworth, 2000). Seen from this perspective, the institutionalization process becomes highly dynamic and recursive rather than static (Machado-da-Silva, Fonseca, \& Crubellate, 2005). Therefore, in our view institutions are more restrictive than inclusive. They impose control, limits, and rules upon individuals and organizations. Those who do not seek to comply with the dictates of institutions cease to be legitimate and are therefore excluded from the game, since they are not willing to play by the rules of the house.

\subsection{Institution-based view}

Since institutions are seen as independent variables, the institution-based view focuses on the dynamic interaction between institutions and organizations, taking into account the strategic choices made as a result of this relationship (Peng, Wang, \& Jiang, 2009). According to these studies, a firm embedded in a particular institutional environment will seek to optimize its performance according to the context in which it operates (Peng \& Luo, 2000).

Emerging economies have been defined in terms of their fast growth and pro-market reforms, as environments in which industries have undergone and are continuing to undergo dramatic structural changes (Luo \& Tung,
2007), and as settings in which markets face institutional deficiencies (Roth \& Kostova, 2003) or institutional voids (Khanna \& Palepu, 2010). Firms from emerging economies use internationalization to gain competitive advantage in foreign and domestic markets through developing and acquiring new capabilities or exploiting their ownership-specific advantages (Gaur, Kumar, \& Singh, 2014). However, emerging economies cannot be generalized, because they include a diverse population of countries. The central and local governments of emerging economies are larger and more active than those of developed economies (Gammeltoft, Barnard, \& Madhok, 2010; Peng, Sun, Pinkham, $\&$ Chen, 2008). Institutions are decisive in the private sector, regarding protection of property rights, capital market transactions, and laws that reduce uncertainty and promote development (Banerjee, Banerji, Duflo, Glennerster, \& Khemani, 2006).

In the context of internationalization, institutions are formal structures responsible for guiding or curtailing the choices of agents with regard to the promotion of their international insertion, and these structures can act in a positive, negative or even indifferent manner.

\subsection{Internationalization strategies from the perspective of the neo-institutional theory}

Neo-institutional theory suggests that an organization's structure and actions are affected by its social environment. This approach has been used in studies about emerging economies, but the term "institutions" has become ubiquitous (Rottig, 2016). The institutional context has three domains - the regulatory (coercive pressures), the normative (normative pressures), and the cognitive (mimetic pressures) (Scott, 2001) and their impact on firms' entry modes can be detected (Arslan, 2012). However, the regulatory environment stands out from the others due to the legal system, governance, and level of transparency of the institutions in foreign countries targeted for 
internationalization efforts (Kostova \& Zaheer, 1999; Scott, 2001). It is important to point out that there are three types of institutional isomorphism that can shape firm behavior: (i) mimetic isomorphism - based on imitation of structural arrangements and successful procedures; (ii) coercive isomorphism - in response to political impositions, legal rules, and state regulations; and (iii) normative isomorphism - the result of influences from professional elements exerted through cognitive construction and consolidation involving a set of norms and work methods shared by the members of professions (DiMaggio \& Powell, 1983; Scott, 2001).

Firms immersed in the internationalization process are constantly involved with institutional systems and subject to the influence of different levels of institutions, but within a dynamic, fragmented, non-linear, and multidimensional environment. Furthermore, given the important role played by firms in the context of internationalization, they rise above the deterministic vision of institutional accommodation, by building, manipulating and negotiating their own institutional environment (Kostova, Roth, \& Dalcin, 2008).

The institutional context influences performance due to organizational capabilities and entry modes into foreign markets. Rigid institutional structures may restrict firms' choices of entry mode (Brouthers, 2002). Wang, Hong, Kafouros and Wright (2012) contend that the effect of government action on the internationalization process of firms varies depending on their resources and capabilities, since different firms have different abilities to internalize the benefits arising from institutional forces. From the perspective of organizational competences, Fleury and Fleury (2011) argue that the sociopolitical and cultural dimensions shape management styles along with the countryspecific factors. Thus, different firms may operate within very similar institutional structures, but, depending on the management characteristics of each one, the results of the institutional influence may vary (Mudambi \& Navarra, 2002).

In summary, formal institutions influence firms' internationalization and facilitate or hinder the process itself. This relationship affects the competitiveness of the industry, according to the proximity between formal institutions and firms in the industry.

\section{Method}

We conducted qualitative research using a descriptive case study approach (Flick, 2009), chosen because of its applicability to the objectives and the complexity of the proposed subject. A qualitative approach is appropriate for the case selected (the Brazilian wine industry) since it is an industry that is still in the early stages of internationalization, is fragmented, and is highly influenced by formal institutions. We interviewed representatives from wineries with a range of different profiles and different sizes and with differing status in terms of membership of business groups, cooperatives, etc. that were judged relevant to map the industry (Creswell, 2010). The wineries were chosen according to these criteria: i) foreign market entry strategy; and ii) stage, according to their activities with the formal institution Wines of Brasil: wineries that have not yet internationalized; those with some international experience; and wineries with a history of international operations.

Data were collected during 21 semistructured interviews with representatives from formal institutions and the foreign trade departments of wineries, from the institutions' and wineries' websites, to supplement the information from the interviews, and from other types of bibliographical material, such as annuals, magazines and books. All interviews were conducted during 2012 and 2013, and were recorded and then transcribed.

Given the qualitative approach, we considered the validity and reliability of the method carefully (Dubé \& Paré, 2003) and composed our interview script using the following a priori categories: characterization of the firm based on the perspective of the formal institution; domestic and international market based on perspective of the industry; internationalization, with a focus on behavioral and economic theories of internationalization; 
and institutional environment, concentrating on the influence formal institutions have on firms' internationalization (Table 1). For data analysis, we employed the content analysis technique, using the categories from the interview script based on the theory (Flick, 2009).

Table 1

Analytical categories used for the interview script

\begin{tabular}{|c|c|c|}
\hline A priori categories & Guiding concepts & Theoretical background \\
\hline Characterization & $\begin{array}{l}\text { History; role and influence of the formal institution; } \\
\text { relevance of the formal institution in the sector. }\end{array}$ & $\begin{array}{l}\text { Characterization of formal } \\
\text { institution }\end{array}$ \\
\hline $\begin{array}{l}\text { Domestic and } \\
\text { international markets }\end{array}$ & $\begin{array}{l}\text { Grouping and relationship strategies; entry barriers; } \\
\text { limitations; Brazil's positioning in the global wine } \\
\text { market; positioning of foreign wines in the Brazilian and } \\
\text { international markets; image of Brazilian wine. }\end{array}$ & $\begin{array}{l}\text { Characterization of the wine } \\
\text { industry and the productive chain in } \\
\text { Brazil and globally }\end{array}$ \\
\hline $\begin{array}{l}\text { Internationalization } \\
\text { processes }\end{array}$ & $\begin{array}{l}\text { Reasons for internationalization, its benefits, results } \\
\text { and difficulties, and adjustments made; international } \\
\text { marketing strategies; entry modes; criteria for selection of } \\
\text { target markets; Wines of Brasil. }\end{array}$ & $\begin{array}{l}\text { Theory of transaction costs; } \\
\text { Internalization; Eclectic Paradigm } \\
\text { (OLI); Psychic Distance; learning } \\
\text { and gradualism; networks. }\end{array}$ \\
\hline $\begin{array}{l}\text { Institutional } \\
\text { environment }\end{array}$ & $\begin{array}{l}\text { Relationship with the formal institution Wines of Brasil; } \\
\text { perceptions of the other formal institutions and their } \\
\text { influence. }\end{array}$ & $\begin{array}{l}\text { Influence of the formal institutions } \\
\text { on internationalization of firms }\end{array}$ \\
\hline
\end{tabular}

The data obtained were used to characterize the institutional environment and the industry's process of internationalization. After these steps, we consolidated the initial categorization based on a classification of elements through differentiation, with previously defined criteria. Finally, NVivo version 10 software was used to manage the relationship between the categories and guiding concepts and between the utterances transcribed from the interviews with the representatives of formal institutions and wineries. After the data collection and analysis, the categories and guiding concepts were validated or improved, arriving at the following a posteriori elements: i) the roles and influence of the formal institutions; ii) criteria for selection of target markets; iii) entry barriers, limitations, international marketing strategies, and positioning of foreign wines in the domestic and international markets; iv) entry modes; v) winery representatives' perceptions of the other formal institutions (i.e. excluding Wines of Brasil) and of their influence; vi) relationship and grouping strategies, such as cooperation, competition and coopetition (Table 2).

Wines of Brasil is considered a crucial factor in the internationalization of wineries and it was analyzed separately from the other formal institutions. On the basis of this re-analysis, we identified prevalent nodes in the speech similarity analysis, with the aim of determining which topics stood out in each category.

Table 2

\section{$A$ priori analytical categories and $a$ posteriori analytical categories}

\begin{tabular}{ll}
\hline A priori categories & A posteriori categories \\
\hline Characterization & Role and influence of the formal institution \\
& $\begin{array}{l}\text { Grouping and relationship strategies } \\
\text { Domestic and International markets }\end{array}$ \\
& $\begin{array}{l}\text { Entry barriers, limitations, international marketing strategies, and positioning of } \\
\text { foreign wines in the domestic and international markets } \\
\text { Criteria for selection of target markets }\end{array}$ \\
Internationalization processes & $\begin{array}{l}\text { Entry mode } \\
\text { Perception and influence of the other formal institutions (except for Wines of Brasil) }\end{array}$ \\
\hline
\end{tabular}


Taking the research question as a starting point, we began by studying the literature on Institutions and Internationalization. We believe that the Brazilian wine industry has characteristics that make it an appropriate subject for studies of the relationship between internationalization and institutional environments because it has recently been the scene of internationalization of firms under the influence of formal institutions. We were able to map this industry based on the data collected. The results will be presented in the following section. Figure 1 summarizes the study procedures, from the initial research question throughout to analysis of the results.

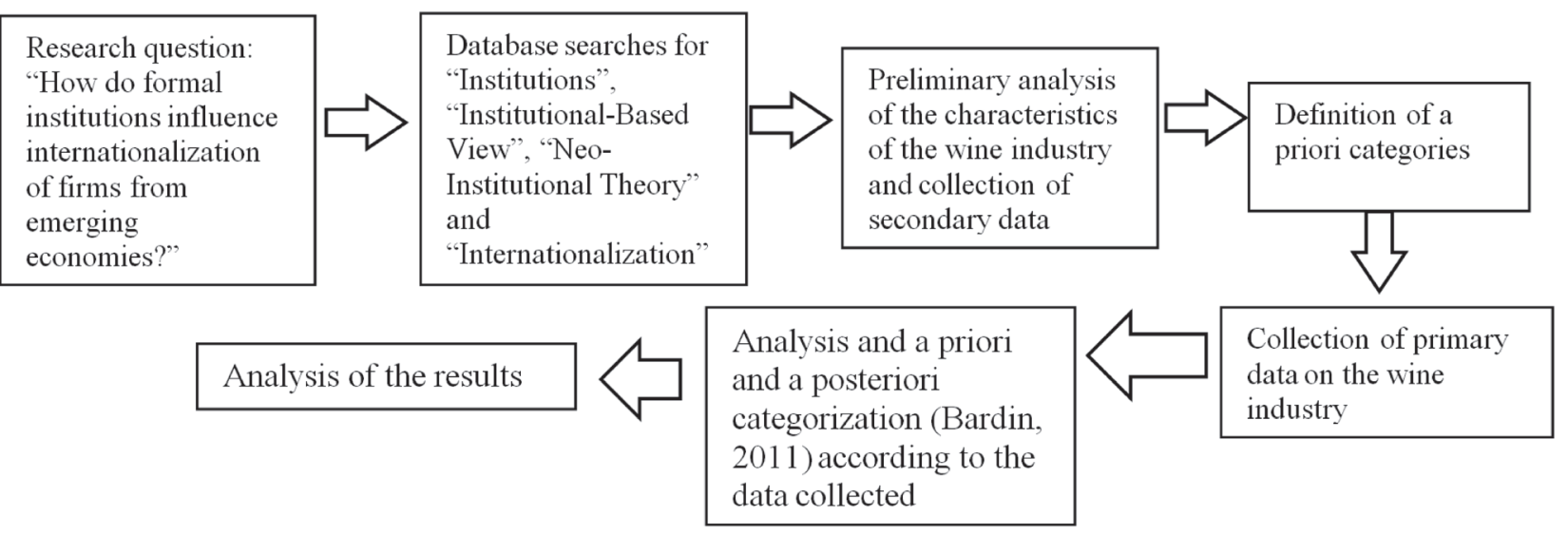

Figure 1. Sequence of study procedures.

\section{The wine industry}

The wine production industry can be subdivided into "Old World" countries, located in the northern hemisphere and comprising Germany, Spain, France, Italy and Portugal, all of which are countries with a historical tradition of wine production, sale, and consumption; and "New World" countries, mostly located in the southern hemisphere and comprising South Africa, Argentina, Australia, Brazil, Chile, United States, New Zealand, and Uruguay, which are countries notable for the variety of grapes grown, technologies used in wine production, and relationship strategies established between wineries, which have resulted in them increasing their share of the world market, production and sales volumes, and consumption.

The five "Old World" countries' share of the international wine trade has been systematically falling in relation to the six "New World" countries' share. In the 1980s, the "Old World" countries accounted for almost $80 \%$ of the international wine trade, while at present they hold a little over $60 \%$. During this same period, "New World" countries have boosted their market share from less than $3 \%$ to $28.4 \%$, and the bulk of this slice has been taken from the "Old World", although some have come from countries in Northwest Africa and Central and Eastern Europe (Organisation Internationale de la Vigne et du Vign [OIV], 2013).

The Brazilian wine industry exports an extensive list of products, in addition to ranking as the $13^{\text {th }}$ largest wine market in the world. Despite the sector's fragmentation, most of its production is concentrated in a small number of firms and these have been responsible for internationalization, selling products that had always competed based on leadership in total cost. It is only recently that the industry has begun to compete based on product differentiation, through efforts to create and market a Brazilian wine identity abroad. Over the past three years, the number of liters exported has risen by $250.66 \%$. Whereas, on the one hand, table wine 
exports have fallen by almost $80 \%$, on the other, fine wine exports have grown by over $520 \%$ (Voltolini, 2013).

Farias (2011) has identified the following difficulties with transforming domestic wineries into internationally competitive firms: i) macroeconomic difficulties; ii) climate problems; and iii) coordination obstacles (due to the fragmentation of the industry in many small firms and the large number of institutions representing the industry).

\section{Formal institutions in the Brazilian wine industry}

The history of the wineries investigated in this study commenced with the arrival of Italian immigrants to Brazil, in the late nineteenth century. It was only in the mid-twentieth century, as regulation of the sector increased, that organizations were created in the wine industry to establish rules and regulations. At the end of the last century, several formal institutions were created, the majority of them with the objective of encouraging internationalization of wineries, based on product differentiation by adopting geographical indication and, more recently, designation of origin. Formal institutions have played and continue to play an important role in the development and consolidation of the wine industry in the state of Rio Grande do Sul, which is Brazil's southernmost state. Furthermore, formal institutions have also fostered relationship strategies based on the participation of wineries and important advances have been made in the internationalization of such firms.

The Brazilian wine industry is notable for the large number of institutional entities established over the years to represent the industry. Specific institutional entities were created or engaged to fill gaps in knowledge, techniques, regulations and legislation. These entities encouraged the growth of the wine industry in the South of Brazil. The first of these were the Brazilian Agricultural Research Corporation (EMBRAPA), which provided growers with techniques and knowledge, and the Federation of Industries of Rio Grande do Sul (FIERGS), which encouraged wineries to unite and form an association, albeit in an incipient manner. Other formal institutions were founded later, including the Wine Industry Syndicate of Rio Grande do Sul (Sindivinho) - an employers' association and the Brazilian Viticulture Union (UVIBRA) - representing the production chain. The Vale dos Vinhedos Association of Fine Wine Producers (APROVALE) was founded in 1995 with a mission to improve skills and promote the region, and the Brazilian Wine Institute (IBRAVIN) was created in 1998 to develop the entire grape and wine production chain, all of which resulted in exponential development of the wine industry in Brazil.

The integrated industry-based project Wines of Brasil was founded in 2002 as an export consortium, organized by FIERGS. It had six member wineries (Casa Valduga, Aurora, Lovara, Salton, Miolo, and De Lantier) who attempted to start internationalization, following a plan involving market research and initial experiments in the international market, through courses, meetings, and international events (Uvibra, retrieved from http://www.uvibra.com.br/, in 2013).

In 2004, APEX-Brasil accredited the export consortium as an integrated industry-wide project, through an agreement with Ibravin, and its initial objective was to promote Brazilian wine in the international market. Wines of Brasil currently has more than 40 member wineries in Rio Grande do Sul, and another ten were recently incorporated into the project from Santa Catarina, another state in South Brazil. The institutional support that Wines of Brasil provides to participating wineries includes financial assistance for firms to exhibit at international events, studies of target markets, training related to the international market, and access to agreements with service providers for sending samples, customs clearance, airline tickets, and other activities related to the foreign market (Wines of Brasil, retrieved from http:// www.winesofbrasil.com, in 2013). 
Wines of Brasil has adopted certain strategies to achieve its goals. According to the project's representative, the most important of these are: using the sporting events hosted in Brazil (FIFA World Cup and Olympics) to promote the image of Brazilian wine abroad; creating a different profile for Brazilian "New World" wine (lighter, fruitier, with moderate alcohol) as opposed to "Old World" wines (stronger, woodier, with higher alcohol content); promoting the image of "Brazil" as a brand; focusing internationalization efforts, together with the wineries, on selected markets identified by studies conducted by ApexBrasil; conducting the Image Project (seeking out and hosting journalists, experts, and sommeliers to introduce the Brazilian wine industry), the Buyer Project (hooking up wineries with international customers), the First Export Program (helping wineries to start their internationalization processes through definition of target markets); adopting practices and procedures, in-company consultancy, participation in courses, training and visits to trade fairs.

In an effort to encourage wineries to internationalize, Apex-Brasil's market intelligence service conducts market research, focused on studying the leading wine importers according to volume and price, the main countries exporting to these markets, market share, and average values paid for "New World" wines, and the importance of target markets as trendsetters. However, each winery determines with which countries it is interested in developing business links. According to the interviewee from Salton winery, they take the following factors into account when choosing markets: prospects for future expansion, the value assigned to the winery's image in that country's market (market tradition), traditional consumers, good trade relations with Brazil, and joint actions with the Wines of Brasil project. As a result, Salton's markets are virtually the same as those of Wines of Brasil.

Although many of the selection criteria used by the wineries and the project are similar, reinforcing mimetic behavior (DiMaggio \&
Powell, 1983), the largest wineries engage in institutional leadership (Lawrence, 1999), guiding the markets chosen by the group. All the winery representatives interviewed also stated that since financial support provided by Wines of Brasil (renting and setting-up stands at trade fairs) is limited to pre-selected markets, many wineries prefer to operate where these benefits are available.

\section{Institutional environment}

The Brazilian wine industry's institutional environment is characterized by fragmentation into numerous formal institutions that seek to represent interests that are sometimes conflicting and sometimes converging. Ibravin, as an aggregating body in the industry, seeks to draw closer to other formal institutions for the sake of a common goal - the Wines of Brasil project. This institution has assumed the role formerly played by FIERGS, which faced certain limitations caused by managing projects in many different industrial sectors in Rio Grande do Sul state.

Representatives of both wineries and other formal institutions cited Ibravin as a formal institution that has a positive influence on wineries' internationalization processes and within the Wines of Brasil project. Ibravin excels in promoting systematic and collective learning in the wine industry through planned exchanges of knowledge and experiences. In order to achieve these results, it needed to gain legitimacy in the view of the firms, which was achieved by a planned and smoothly-orchestrated transition, taking over responsibility for management of Wines of Brasil from FIERGS.

The interviewees emphasized the importance of the financial support provided by Apex-Brasil. Some referred to the technical studies and knowledge that it brings to the sector, especially those from larger wineries. The only negative point mentioned in relation to this agency was that some felt the financial funding it provided could be increased, but it was also understood that the institution is responsible for several projects at the same time. 
The main resource Wines of Brasil provides to wineries is its knowledge of the stages that comprise the internationalization process. This strategic resource includes information on grape growing based on international market standards, the wine making process, selling the product, marketing it, and strategies for internationalization. Formal institutions provide the wineries with access to training, improvements to production and trading processes, and help to expand networks and access international markets through industry-wide projects.

Even wineries that are not yet internationalized attest the potential of Wines of Brasil and the initiatives it has implemented, which generate visibility in foreign and domestic markets. Therefore, even firms that do not participate in Wines of Brasil, have less capacity for investment, and do not allocate resources to the project, can share in the benefits.

Aprovale and Embrapa were mentioned as partner organizations for obtaining designation of origin accreditation, and as assisting in research and studies, in addition to other institutional bodies cited, such as the University of Caxias do Sul, the Federal University of Rio Grande do Sul, the Brazilian Support Service for Micro and Small Enterprises (SEBRAE), the Studies and Projects Finance Agency (FINEP) and the Research Support Foundation of Rio Grande do Sul (FAPERGS). Sebrae was the formal institution that came up most frequently in the interviews, especially with representatives from smaller wineries. It acts as an operational partner to Ibravin, responsible for professional training of winery personnel, according to interviewees from Wines of Brasil.

At the State level, interviewees highlighted FIERGS and the State Department of Economic Development, Science and Technology (SDECT). After the Wines of Brasil project was transferred to Ibravin, FIERGS has become rather isolated in the wine industry. The representative from SDECT also stated that they do not work together with FIERGS or Sebrae, as they do in other industries.
To make matters worse, there is also no culture of working with benchmarks or feedback between wineries and institutional entities, which would enable the evaluation of projects and events. At the Federal level, besides Apex-Brasil, only the Ministry of Foreign Relations (MRE) was cited as having a positive institutional influence. On the other hand, the following formal institutions were all mentioned as adversely affecting or making a limited contribution to the wineries' internationalization processes: Ministry of Agriculture, Livestock and Supply, because of red tape; the National Health Surveillance Agency (ANVISA), because of norms and legal barriers that make exporting to other countries more difficult; and customs brokers because of technical failures.

Another approach taken in this study was to identify the institutional factors that hinder the internationalization of the industry. Despite the diversity of the formal institutions and firms whose representatives were interviewed, the answers given were linear. The main institutional factors that interviewees considered as limiting the internationalization of the wine industry were as follows: bureaucracy of foreign formal institutions, unfavorable exchange rates, lack of recognition of Brazilian wine, and high taxation in the domestic market.

\section{Institutional influences}

The interview transcriptions were analyzed to identify utterances that indicated the influence exerted by elements of the cognitive, normative, and regulatory domains of the institutional context (Scott, 2001) on the wine industry, and the prevalent formal institutions involved were identified. The influence of the cognitive domain (Scott, 2001) on wine consumption in the Brazilian market was identified with the input from representatives of Apex-Brasil, Embrapa, and Miolo who explained that this market is regulated by supply, rather than demand, unlike other sectors. The Embrapa representative explained this claim, pointing out 
that Brazilians' wine consumption is very much dependent on the products that waiters offer, that specialists recommend, that retail outlets display on their stands, or that specialty stores promote. In turn, the interviewee from Miolo added that consumption is based on status, since the public lacks understanding of the products available. As a result, wine is still viewed as a sophisticated product that one must be knowledgeable about to appreciate and, in the absence of this knowledge, consumers seek to validate their decisions by following similar patterns of behavior, basing decisions on factors such as recommendations, awards, and exhibitions, in order to minimize risks and legitimize their decisions.

In another part of the chain, the influence of the cognitive domain (Scott, 2001) is manifested in the pursuit of technical knowledge at formal institutions such as Embrapa, Sebrae, and partner universities. Embrapa is responsible for providing technological solutions to the industry through studies and research, and Sebrae is responsible for improving quality in production and commercialization of wine. In both cases, mimetic forces of the institutional context lead to isomorphic behavior (DiMaggio \& Powell, 1983; Scott, 2001) by wineries when they result in a prevailing cognitive pattern across companies that all comply with standards established by the formal institutions. This approach reinforces the view of coopetition in which agents (larger and smaller wineries) cooperate and compete simultaneously, but in different areas (marketing, foreign trade, and commercialization), aiming to generate value for all of those involved (creating an identity for the domestic wine) by sharing resources and knowledge to achieve higher returns than would be achieved working separately (in this case the gain in international market share) and which will be divided up further down the line.

The progressive convergence to a pattern of uniformity among wineries is evident. The majority of this is the result of Wines of Brasil's activities, which bring together all of the organizations and institutional entities working with coercive isomorphism (deriving from political influence and legitimacy problems) and mimetic isomorphism (due to the standardization of responses to uncertainty) (DiMaggio \& Powell, 1983).

If, on the one hand, formal institutions promote the entry of wineries into the international market, on the other, they indirectly favor larger wineries with more professional structures, since they are the best equipped to reap the benefits resulting from internationalization. There is a reinforcement of the positive image of formal institutions that, from a political perspective, secure increased funding from governments to be reinvested in the industry. According to the ApexBrasil representative, their industry-wide projects generally last two years, but Wines of Brasil, which is affiliated with Apex-Brasil (as an accredited industry-wide project), exists since 2004 and is one of the projects that has had the best results out of more than eighty projects managed by the institution, as is manifest in the fact that the agreement has been renewed every two years in recognition of the results it has achieved.

The government's role is as a factor of integration that acts to unite the industry through formal institutions assigned to promote the Wines of Brasil project, such as Apex-Brasil, Ibravin, SDECT, FIERGS, and Wines of Brasil itself. These institutions have rallied the wineries around a common goal, through mechanisms identified as belonging to the cognitive and regulatory domains (Scott, 2001). However, with relation to the regulatory domain, in a study by Calixto, Monticelli, Garrido and Vasconcellos (2012) it was clear that complete and absolute understanding of the rules and requirements for wineries to participate in the Wines of Brasil project was lacking, and these authors suggested that Ibravin should provide more information, in order to avoid doubts on the part of member wineries.

The normative domain is characterized by the efforts to unite the wineries to work towards common objectives (DiMaggio \& 
Powell, 1983). However, the main difficulties have been to extirpate feelings of mistrust and competition between business families, to overcome socioeconomic differences between firms, to preserve family values, and to promote professionalization in the industry. A similar situation was observed among the formal institutions, since there is a large number of different trade associations, revealing a highlyfragmented sector involving conflicting and overlapping interests. Consequently, the wineries have a low level of commitment to the formal institutions, with high turnover of membership and withdrawal from them and varying levels of commitment.

Creation of the Wines of Brasil project changed the business dynamics among producers of fine wine in Rio Grande do Sul state. Even those wineries that were already active in foreign markets benefited from the project and expanded their efforts, while firms with no plans to export saw the project as an opportunity to diversify markets and improve the image of wine in the domestic market, as a result of gaining international recognition. In all of the wineries, regardless of size, the practices needed to prepare firms to achieve the quality needed for the international market were transposed to the domestic market, thereby boosting the competitiveness of the Brazilian wine industry. However, there is a relationship of interdependence since one winery performing badly in a given market could undermine the entry of others and tarnish the image of Brazilian wine (Zen, Dalmoro, Fensterseifer, \& Wegner, 2013) (Table 3).

Table 3

\section{Institutional influences and their manifestations}

\begin{tabular}{|c|c|}
\hline Positive influences & Manifestations \\
\hline Learning & Training of wineries, enhancement of products, and improvement of processes \\
\hline Relationship networks & Wines of Brasil, Ibravin, Aprovale \\
\hline Relationship strategies & Coopetition \\
\hline $\begin{array}{l}\text { Generation of intelligence about } \\
\text { foreign markets }\end{array}$ & $\begin{array}{l}\text { Market studies sponsored and conducted by formal } \\
\text { institutions }\end{array}$ \\
\hline $\begin{array}{l}\text { Production and dissemination of } \\
\text { technical knowledge }\end{array}$ & Research and solutions that link knowledge and innovation to the industry \\
\hline Cost reductions & $\begin{array}{l}\text { Government incentive programs for the industry through } \\
\text { formal institutions }\end{array}$ \\
\hline \multirow{2}{*}{ Internationalization of business } & Representation of the industry through formal institutions \\
\hline & Operational, commercial and financial support of other formal institutions \\
\hline $\begin{array}{l}\text { Promotion of Brazil as a wine } \\
\text { producer }\end{array}$ & Creation and marketing of "Brazil brand" for wine by formal institutions \\
\hline Negative influences & Manifestations \\
\hline $\begin{array}{l}\text { Increased costs and loss of } \\
\text { competitiveness }\end{array}$ & $\begin{array}{l}\text { Bureaucracy and strikes; legal barriers to exportation, institutions' insufficient } \\
\text { technical knowledge; high tax burden }\end{array}$ \\
\hline Political bias of formal institutions & Favoring of the largest wine producers in the industry \\
\hline Variable influences & Manifestations \\
\hline Imitation & Success and failure are possible results of imitating the strategies of other wineries \\
\hline
\end{tabular}


Table 4 identifies the influences of formal institutions on participants from the wine industry in South Brazil and the institutional domains in which they act. It also indicates the ways in which they affect the internationalization of firms doing business in this sector. It summarizes the findings accumulated during the course of the research, highlighting the similarities and discrepancies between the formal institutions' original functions and the ones they effectively carry out. Wines of Brasil stands out for its work in all three institutional domains and for its positive influence on the wine industry, although it is not immune to downsides. Additionally, Ibravin and Apex-Brasil work in the cognitive and regulatory institutional domains and have a positive influence on the industry.

The main resource acquired by the wineries through Wines of Brasil is knowledge of the stages that make up the internationalization process, generating learning that has been disseminated throughout the network. This strategic resource starts with growing grapes to the recommended standards demanded by the international market and continues through the winemaking process, product commercialization, and strategies for marketing and internationalization.

This strategy has been reflected in the image of Brazilian wine in foreign markets, generating gains for the national wine industry as a whole. However, some industry conditions, such as competition with foreign wines in the domestic market, the need to increase the scale of production (which is still low compared to other countries that are leaders in the global wine industry), composed of the availability of resources and the quality of the wine, are still limiting the wineries' strategies. Further restrictions were also identified, such as fierce competition between Brazilian firms in the domestic market, the lack of professional management at most wineries (which are still family-owned and managed), and inequality of resources between the participants irrespective of whether they are committed or not committed to Wines of Brasil. 


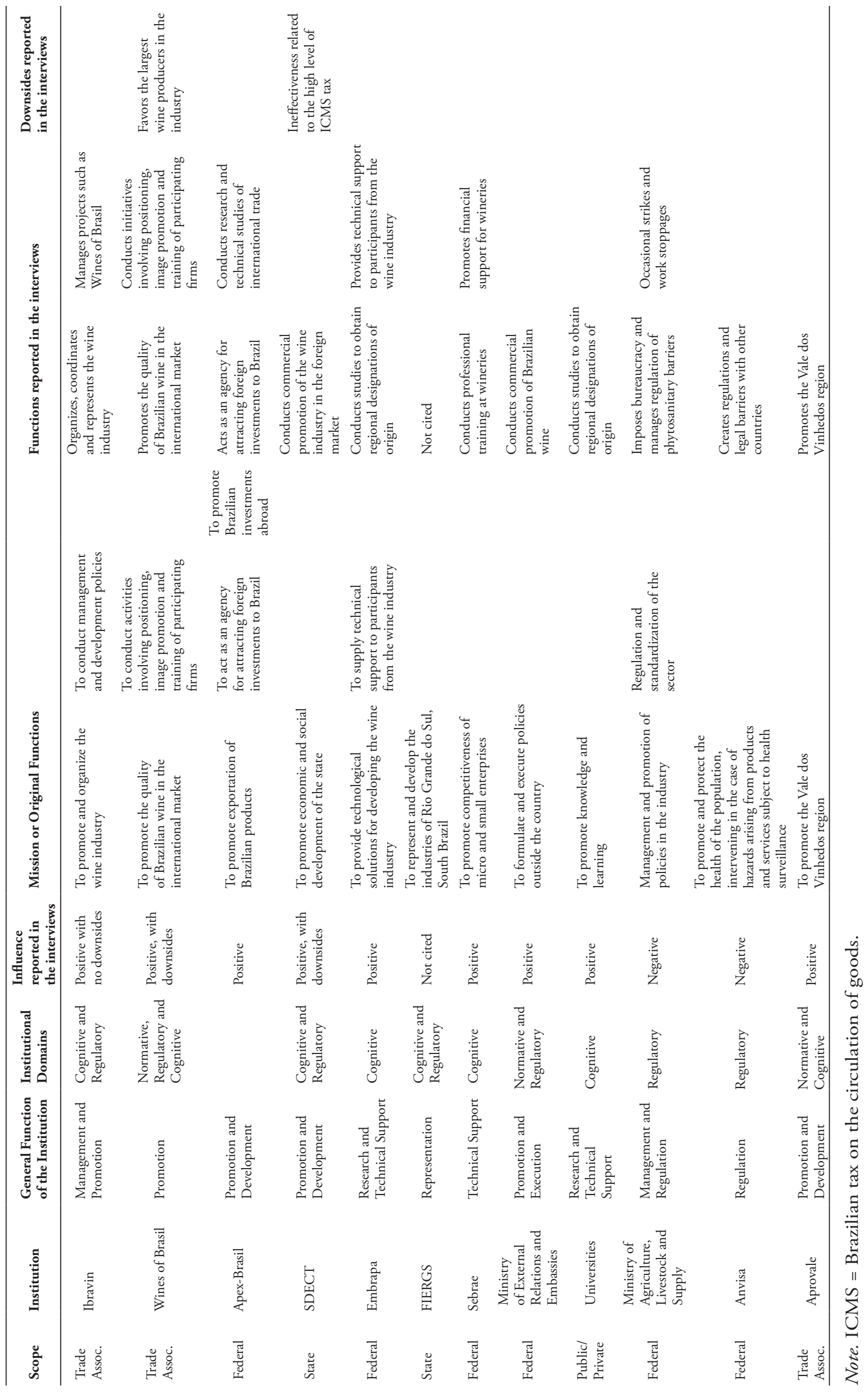




\section{Final considerations}

This study has assessed the relationship between the institutional environment and internationalization of firms from an emerging economy. In the wine industry, with the entry of firms into the foreign market, the paradigm became how to deal with the institutional environment in the host countries. Hence, home-country formal institutions are seen as promoters of networks, providing assistance for dissemination of learning among participants. Given this context, internationalization takes on importance as a source of competitiveness for firms, since they partake in the benefits offered, and it contextualizes them in the institutional system in which they are inserted.

The goals of internationalization extend beyond market expansion and increased sales and profits, and include building relationship networks and generating learning. The effort of promoting Brazilian wine in the international market plays a very important role in the wine industry, considering the importance of products' countries of origin. As the wineries evolve, sources of competitiveness are generated and lead to new and more ambitious goals, which is enabling Brazilian wineries to take a larger share of the international market.

This study has also demonstrated the roles Ibravin plays as an institutional leader for wineries targeting the foreign market, that ApexBrasil plays as an investment agent, and that the Wines of Brasil project plays as an initial and lasting framework for the international activities of many wineries. There were benefits from participating in the project, since many firms only had access to international trade fairs and business roundtables due to their interaction with the formal institutions. Furthermore, the importance of the institutional environment can be detected, at the country level, as a positive element for internationalization. The project had a significant influence on wineries' decision-making in relation to the internationalization process, whether by providing assistance for participation in trade fairs abroad, by training wineries for foreign trade activities, or by conducting market research and organizing business roundtables.

The wineries understand that internationalization, even on a small scale, generates important benefits for the industry as a whole, since it enhances the visibility of Brazilian wine, thereby boosting the competitiveness of national firms. In the case of the wine industry, internationalization is fostered by formal institutions. As a result, firms acquire sources of competitiveness to compete in international markets, prioritizing countries with greater geographic, cultural, and psychic distance in relation to Brazil.

This study shows that the institutional environment in the wine industry in Rio Grande do Sul can favor participants in the internationalization process, but it has also revealed factors that need improvement for the sake of greater synergistic gains among the members of the Wines of Brasil project. Within the cognitive domain, one of the most urgent objectives is to mobilize resources in the pursuit of new designations of origin, by certifying specific environmental characteristics that confer legitimacy to products from these regions that attain a certain level of quality. This is followed by isomorphic behavior by the other members producing in these regions, which generates uniformity of productive and commercial practices. In the normative domain, representatives from each winery need to be drawn even closer, to mitigate feelings of distrust, or competition, and the professionalism of organizational management must be increased. In the regulatory domain, it is essential to clarify and publicize the rules and regulations that guide the project, enhancing its credibility and making it more attractive to new entrants.

Another detrimental factor that limits wineries' membership of and commitment to projects such as internationalization is related to the large number of formal institutions seeking 
to represent the interests of the firms. As a result, there are both similarities and discrepancies in the visions of the representative bodies, creating fragmentation in the sector that affects resources and membership and interferes with the wineries' perceptions of the influence of these formal institutions.

One avenue for future research that was only approached tangentially in this study concerns the relationship strategies established by the wineries and how they impact upon the internationalization of the network of firms. Finally, it would be worthwhile to explore how decisions of a political nature made by formal institutions influence the wine industry, providing a new outlook on the internationalization of these firms.

\section{References}

Arslan, A. (2012). Impacts of institutional pressures and the strength of market supporting institutions in the host country on the ownership strategy of multinational enterprises: Theoretical discussion and propositions. Journal of Management and Governance, 16(1), 107-124.

Banerjee, A., Banerji, R., Duflo, E., Glennerster, R., \& Khemani, S. (2006). Can information campaigns spark local participation and improve outcomes? A study of primary education in Uttar Pradesh, India [Working Paper 3967]. World Bank Policy Research. Retrieved from http://siteresources. worldbank.org/DEC/Resources/Khemani_ CanInformationCampaignsRaise.pdf

Bardin, L. (2011). Análise de conteúdo. São Paulo: Edições 70.

Brouthers, K. D. (2002). Institutional, cultural and transaction cost influences on entry mode choice and performance. Journal of International Business Studies, 33(2), 203-221.

Calixto, C. V., Monticelli, J. M., Garrido, I. L., \& Vasconcellos, S. L. (2012). The influence of the institution in the process of internationalization of Serra Gaucha region wineries. Proceedings of the Annual Conference Academy of International Business - AIB, Fort Lauderdale, Florida.

Creswell, J. W. (2010). Projeto de pesquisa: Métodos qualitativo, quantitativo e misto (3rd ed.). Porto Alegre: Artmed/Bookman.

DiMaggio, P., \& Powell, W. (1983). The iron cage revisited: Institutional isomorphism and collective rationality in organizational fields. American Sociological Review, 48(2), 147-160.

Dubé, L., \& Paré, G. (2003). Rigor in information system positivist case research: Current practices, trends, and recommendations. MIS Quarterly, 27(4), 597-635.

Farias, C. V. S. (2011, maio). Inovação e ganhos competitivos na vitivinicultura gaúcha: Uma abordagem preliminar. Anais Congresso do Instituto Franco-Brasileiro de Administração de Empresas, Franca, SP, Brasil, 6. Recuperado de http:// www.apec.unesc.net/IV_EEC/sessoes_ tematicas/Economia\%20industrial,\%20 ci\%EAncia,\%20tecnologia\%20e\%20 inova $\% \mathrm{E} 7 \% \mathrm{E} 3$ o/Inova $\% \mathrm{E} 7 \% \mathrm{E} 30 \% 20$ e\%20ganhos\%20competitivos\%20na\%20 vitivinicultura $\% 20$ ga $\%$ FAcha $\% 20$ uma $\% 20$ abordagem $\% 20$ preliminar.pdf

Fleury, A., \& Fleury, M. T. L. (2011). Brazilian multinationals: Competences for internationalization. Cambridge: Cambridge University.

Flick, U. (2009). Desenho da pesquisa qualitativa. Porto Alegre: Artmed.

Gammeltoft, P., Barnard, H., \& Madhok, A. (2010). Emerging multinationals, emerging theory: macro and micro-level perspectives. Journal of International Management, 6(1), 95-101. 
Gao, G. Y., Murray, J. Y., Kotabe, M., \& Lu, J. (2010). A "strategy tripod" perspective on export behaviors: Evidence from domestic and foreign firms based in an emerging economy. Journal of International Business Studies, 41(3), 377-396.

Gaur, A. S., Kumar, V., \& Singh, D. (2014). Institutions, resources, and internationalization of emerging economy firms. Journal of World Business, 49(1), 12-20.

Greenwood, R., Oliver, C., Suddaby, R., \& Sahlin, K. (Eds.). (2008). The SAGE handbook of organizational institutionalism. London: SAGE Publications Ltd.

Hollingsworth, J. R. (2000). Doing institutional analysis: Implications for the study of innovations. Journal of International Business Studies, 7(4), 595-644.

Hoskisson, R. E., Eden, L., Lau, C. M., \& Wright, M. (2000). Strategy in emerging economies. Academy of Management Journal, 43(3), 249-267.

Khanna, T., \& Palepu, K. (2010). Winning in emerging markets: A road map for strategy and execution. Cambridge, MA: Harvard Business School Press.

Kostova, T., Roth, K., \& Dalcin, T. (2008). Institutional theory in the study of MNCs: A critique and new directions. Journal of Management and Governance, 33(4), 9941007.

Kostova, T., \& Zaheer, S. (1999). Organizational legitimacy under conditions of complexity: The case of multinational enterprise. Academy of Management Review, 24(1), 64-81.

Lawrence, T. B. (1999). Institutional strategy. Journal of Management, 25(2), 161-188.

Luo, Y., \& Tung, R. L. (2007). International expansion of emerging market enterprises: A springboard perspective. Journal of International Business Studies, 38(4), 481-498.

Machado-da-Silva, C. L., Fonseca, V., Crubellate, J. M. (2005). Unlocking the institutionalization process: Insights for an institutionalizing approach. Brazilian Administration Review, 2(1), 1-20.

Meyer, K. E., \& Peng, M. W. (2005). Probing theoretically into Central and Eastern Europe: Transactions, resources, and institutions. Journal of International Business Studies, 36(6), 600-621.

Mudambi, R., \& Navarra, P. (2002). Institutions and international business: A| theoretical overview. International Business Review, 11(6), 635-646.

North, D. C. (1990). Institutions, institutional change and economic performance. Cambridge: Cambridge University Press.

Organisation Internationale de la Vigne et du Vign. (2013). Statistical report on world Vitiviniculture 2012. Retrieved from http:// www.oiv.int

Peng, M. W. (2002). Towards an institution-based view of business strategy. Asia Pacific Journal of Management, 19(2/3), 251-267.

Peng, M. W., \& Khoury, T. A. (2008). Unbundling the institution-based view of international business strategy. In A. M. Rugman (Ed.), Oxford handbook of international business (Cap. 10, pp. 256-268). Oxford: Oxford University Press.

Peng, M. W., \& Luo, Y. (2000). Managerial ties and firm performance in a transition economy: The nature of a micro-macro link. Academy of Management Journal, 43(3), 486-501.

Peng, M. W., Sun, S. L., Pinkham, B., \& Chen, H. (2008). The institution-based view as a 
third leg for a strategy tripod. Academy of Management Perspectives, 23(3), 63-81.

Peng, M. W., Wang, D., \& Jiang, Y. (2009). An institution-based view of international business strategy: A focus on emerging economies. Journal of International Business Studies, 39(5), 920-936.

Rocha, A., Silva, J. F., \& Carneiro, J. (2007). Expansäo internacional das empresas brasileiras: Revisão e sintese. São Paulo: Atlas.

Roth, K., \& Kostova, T. (2003). The use of the multinational corporation as a research context. Journal of Management, 29(6), 883-902.

Rottig, D. (2016). Institutions and emerging markets: effects and implications for multinational corporations. International
Journal of Emerging Markets, 11(1), 2-17.

Scott, W. R. (2001). Institutions and organizations. London: Sage Publications.

Voltolini, A. (Ed.). (2013). Revista anuário vinhos dos Brasil. Rio de Janeiro: Intergraf.

Wang, C., Hong, J., Kafouros, M., \& Wright, M. (2012). Exploring the role of government involvement in outward direct investment from emerging economies. Journal of International Business Studies, 43(7), 655676.

Zen, A., Dalmoro, M., Fensterseifer, J., \& Wegner, D. (2013). O desenvolvimento de recursos em redes interorganizacionais e $\mathrm{o}$ processo de internacionalização: $\mathrm{O}$ caso Wines of Brasil. Revista Ibero-Americana de Estratégia, 12(1), 107-130.

\section{About the authors:}

1. Jefferson Marlon Monticelli, Doctoral Candidate in Business Administration, University of Vale do Rio dos Sinos, Brazil. E-mail: jeffmarlon@hotmail.com.

2. Cyntia Vilasboas Calixto, Doctor in Administration, Getúlio Vargas Foundation/EAESP, Brazil. E-mail: cyntia.calixto@fgv.br.

3. Sílvio Luís de Vasconcellos, Postdoctoral Fellow in Business, University of Vale do Itajaí, Brazil. E-mail: silviolvasconcellos@gmail.com.

4. Ivan Lapuente Garrido, Postdoctoral in International Business, Florida International University, EUA.

E-mail: igarrido@unisinos.br

Contribution of each author:

\begin{tabular}{|c|c|c|c|c|}
\hline Contribution & $\begin{array}{c}\text { Jefferson Marlon } \\
\text { Monticelli }\end{array}$ & $\begin{array}{l}\text { Cyntia Vilasboas } \\
\text { Calixto }\end{array}$ & $\begin{array}{l}\text { Sílvio Luís de } \\
\text { Vasconcellos }\end{array}$ & $\begin{array}{c}\text { Ivan Lapuente } \\
\text { Garrido }\end{array}$ \\
\hline 1. Definition of research problem & $\sqrt{ }$ & & & $\sqrt{ }$ \\
\hline $\begin{array}{l}\text { 2. Development of hypotheses or research questions } \\
\text { (empirical studies) }\end{array}$ & $\sqrt{ }$ & & & $\sqrt{ }$ \\
\hline $\begin{array}{l}\text { 3. Development of theoretical propositions } \\
\text { (theoretical Work) }\end{array}$ & $\sqrt{ }$ & & & $\sqrt{ }$ \\
\hline 4. Theoretical foundation/ Literature review & $\sqrt{ }$ & $\sqrt{ }$ & $\sqrt{ }$ & $\sqrt{ }$ \\
\hline 5. Definition of methodological procedures & $\sqrt{ }$ & $\sqrt{ }$ & $\sqrt{ }$ & $\sqrt{ }$ \\
\hline 6. Data collection & $\sqrt{ }$ & $\sqrt{ }$ & & \\
\hline \multicolumn{5}{|l|}{ 7. Statistical analysis } \\
\hline 8. Analysis and interpretation of data & $\sqrt{ }$ & & & $\sqrt{ }$ \\
\hline 9. Critical revision of the manuscript & & $\sqrt{ }$ & $\sqrt{ }$ & $\sqrt{ }$ \\
\hline 10. Manuscript Writing & $\sqrt{ }$ & $\sqrt{ }$ & $\sqrt{ }$ & \\
\hline
\end{tabular}

